\title{
KONSUMSI KAYU BAKAR RUMAH TANGGA PEDESAAN DAN FAKTOR-FAKTOR YANG MEMPENGARUHI DI KABUPATEN BANJARNEGARA JAWA TENGAH, SUKABUMI JAWA BARAT DAN LEBAK BANTEN (Fuelwood Consumption of Rural Housebolds and Its Determinant Factors in Banjarnegara Central Java, Sukabumi West Java and Lebak Banten Districts)
}

\author{
Satria Astana \\ Puslitbang Perubahan Iklim dan Kebijakan Kehutanan \\ Jl. Gunung Batu No. 5, Bogor \\ Email: astanasatria@yahoo.com
}

Diterima 8 Oktober 2012, disetujui 30 November 2012

\begin{abstract}
The development of fuelwood consumption of rural households might cause pressures to surrounding state forests sustainability. This research aims to find the consumption and factors affecting the monthly fuelwood consumption of rural households in three districts, i.e. Banjarnegara (Central Java Province), Sukabumi (West Java Province), and Lebak. (Banten Province). The data on fuelwood consumption by rural households of each district were collected using stratified purposive sampling method. Factors affecting consumption were analysed using econometric model. The result of research reveals that the monthly fuelwood consumption by a rural household in three districts studied ranged from $165256 \mathrm{kgs}$. However, the fuelwood consumption in such three district did not imply as a pressure to surrounding state forests sustainability as $93 \%$ of fuelwood consumed was gathered from estate areas. The fuelwood consumption was found elastic to its price changes. These three findings imply that afforestation program is necessary to be continuously implemented so that reduction to pressure of such households fuelwood consumption remains being able to be maintained. The other finding shows that the effect of kerosene price drew attention as it affected the fuelwood consumption in negative relation, reflecting that the kerosene is not a substitute but a complementary goods for fuelwood. The income of households also affected the consumption in negative relation, reflecting that higher income of households tends to consume less fuelwood and vise versa. These two findings imply thatprice subsidy reduction policy on kerosene if implemented, whether it will have negative or positive impact on surrounding state forests sustainability, depends on the magnitute of households income and kerosene price elasticities. As the elasticity of kerosene price (-2.0) was found greater than households income elasticity $(-0,89)$, its impact is predicted tending to be positive and hence anticipative policy to its impact in three districts studied is not needed if kerosene price subsidy reduction policy is implemented.
\end{abstract}

Keywords: fuelwoods, forest, sustainability, consumption, household, rural

\begin{abstract}
ABSTRAK
Perkembangan konsumsi kayu bakar rumah tangga pedesaan dikhawatirkan sebagai tekanan terhadap kelestarian hutan negara sekitar. Penelitian ini bertujuan untuk mengetahui besarnya konsumsi kayu bakar rumah tangga pedesaan dan faktor-faktor yang mempengaruhi di tiga kabupaten, yaitu: Banjarnegara (Provinsi Jawa Tengah), Sukabumi (Provinsi Jawa Barat), dan Lebak (Provinsi Banten). Pengumpulan data konsumsi kayu bakar oleh rumah tangga pedesaan di masing-masing kabupaten dilakukan menggunakan metode pengambilan contoh stratifikasi disengaja. Faktor-faktor yang mempengaruhi konsumsi dianalisis menggunakan model ekonometrika. Hasil penelitian menunjukkan bahwa konsumsi kayu bakar bulanan rumah tangga pedesaan di tiga kabupaten yang diteliti berkisar antara 165 - $256 \mathrm{~kg}$. Namun konsumsi kayu bakar di tiga kabupaten tersebut tidak dapat disimpulkan sebagai tekanan terhadap kelestarian hutan negara sekitar, karena $93 \%$ kayu bakar yang dikonsumsi diperoleh dari areal kebun. Konsumsi kayu bakar ditemukan peka terhadap perubahan harganya. Tiga temuan ini menyarankan bahwa program penghijauan perlu terus dilaksanakan sehingga pengurangan terhadap tekanan konsumsi kayu bakar rumah tangga tersebut tetap dapat dipertahankan. Temuan yang lain menunjukkan bahwa pengaruh harga minyak tanah menarik perhatian karena mempengaruhi konsumsi kayu bakar dalam hubungan negatif, yang merefleksikan
\end{abstract}

Konsumsi Kayu Bakar Rumah Tangga Pedesaan dan Faktor-faktor yang Mempengaruhi di Kabupaten ..... (Satria Astana) 
bahwa minyak tanah bukan merupakan barang substitusi tetapi barang komplementer kayu bakar. Pendapatan rumah tangga pedesaan juga mempengaruhi dalam hubungan negatif, yang merefleksikan bahwa rumah tangga pedesaan dengan pendapatan tinggi cenderung mengkonsumsi kayu bakar lebih kecil, dan sebaliknya. Dua temuan ini menyarankan bahwa kebijakan pengurangan subsidi harga minyak tanah jika dilaksanakan, apakah akan berdampak negatif atau positif terhadap kelestarian hutan negara sekitar, bergantung pada besarnya elastisitas pendapatan rumah tangga dan harga minyak tanah. Karena elastisitas harga minyak tanah $(-2,0)$ ditemukan lebih besar dibanding elastisitas pendapatan rumah tangga (-0,89), dampaknya dipredikasi cenderung positif dan karenanya kebijakan antisipatif terhadap dampaknya di tiga kabupaten yang diteliti tidak diperlukan jika kebijakan pengurangan subsidi harga minyak tanah dilaksanakan.

Kata kunci: kayu bakar, hutan, kelestarian, konsumsi, rumah tangga, pedesaan

\section{PENDAHULUAN}

Konsumsi kayu bakar rumah tangga pedesaan disini didefinisikan sebagai jumlah kayu yang dikonsumsi oleh individu rumah tangga pedesaan sebagai bahan bakar untuk memasak. Pasar kayu bakar dapat dibedakan antara pasar rumah tangga dan pasar industri. Perkembangan konsumsi kayu bakar oleh rumah tangga dan industri dikhawatirkan dapat menimbulkan tekanan terhadap kelestarian hutan negara sekitar, khususnya di daerah-daerah padat penduduk. Antisipasi tentunya diperlukan agar kelestarian hutan tetap terjaga. Dalam kaitan ini, informasi pasar kayu bakar, khususnya dari sisi konsumsi diperlukan.

Sejauh ini, pasar kayu bakar rumah tangga kurang mendapatkan perhatian, khususnya dari sisi pasokan. Ini dapat dipahami selama pendapatan rumah tangga pedesaan yang umumnya sangat rendah membeli kayu bakar dipandang sebagai suatu pemborosan. Kebutuhan kayu bakar rumah tangga dipenuhi sendiri dengan cara memungut di kebun atau hutan negara terdekat. Sebaliknya, rumah tangga pedesaan dengan pendapatan tinggi membeli minyak tanah atau gas LPG, sedangkan kayu bakar yang dipungut di kebun atau dibeli di warung atau pasar diperlukan sebagai tambahan jika terjadi kekurangan.

Menurut Tomek dan Robinson (1985), faktorfaktor yang mempengaruhi permintaan dibedakan ke dalam empat kelompok: (1) jumlah penduduk dan penyebarannya menurut umur dan geografi, (2) pendapatan konsumen dan distribusinya, (3) harga dan keberadaan komoditas serta pelayanan lain, dan (4) cita rasa dan selera konsumen. Selaras dengan Tomek dan Robinson (1985), konsumsi kayu bakar rumah tangga pedesaan dihipotesiskan dipengaruhi oleh harganya, harga barang lain (minyak tanah dan gas LPG), pendapatan, umur, pendidikan, pekerjaan, jumlah anggota keluarga, luas kepemilikan lahan, dan lokasi penduduk.

Seberapa besar faktor-faktor tersebut mempengaruhi konsumsi kayu bakar rumah tangga pedesaan dan apakah besarnya konsumsi rumah tangga pedesaan dapat dipandang sebagai tekanan terhadap kelestarian hutan negara sekitar merupakan dua persoalan yang perlu diketahui, dan untuk itu penelitian ini dilakukan. Penelitian bertujuan untuk mengetahui besaran dan faktorfaktor yang mempengaruhi konsumsi kayu bakar rumah tangga pedesaan. Hasil penelitian diharapkan bermanfaat sebagai bahan pertimbangan dalam mengantisipasi tekanan konsumsi kayu bakar terhadap kelestarian hutan negara sekitar.

\section{METODE PENELITIAN}

\section{A. Lokasi Penelitian}

Penelitian dilaksanakan tiga kabupaten yang diketahui sebagai kabupaten konsumen kayu bakar, yaitu: (1) Banjarnegara (Provinsi Jawa Tengah), (2) Sukabumi (Provinsi Jawa Barat), dan (3) Lebak (Provinsi Banten). Pengumpulan data konsumsi kayu bakar oleh rumah tangga pedesaan di masingmasing kabupaten dilakukan menggunakan metode pengambilan contoh startifikasi disengaja. Berdasarkan informasi dari dinas kabupaten yang berwenang di bidang kehutanan, di masing-masing kabupaten dipilih secara sengaja kecamatan contoh, yaitu: (1) Punggelan dan (2) Banjarmangu, Kabupaten Banjarnegara, (3) Jampang Tengah, Kabupaten Sukabumi, dan (4) Rangkas Bitung, Kabupaten Lebak. Berdasarkan informasi dari 
petugas penyuluh kecamatan, di masing-masing kecamatan kemudian dipilih secara sengaja desa contoh, yaitu: (1) Bondolharjo dan (2) Karangsari, Kecamatan Punggelan, (3) Pekandangan, Kecamatan Banjarmangu, (4) Sindangresmi dan (5) Padabeunghar, Kecamatan Jampang Tengah, dan (6) Rangkas Bitung Timur dan (7) Jatimulya, Kecamatan Rangkas Bitung. Akhirnya berdasarkan informasi dari aparat desa, di masing-masing desa dipilih rumah tangga contoh secara sengaja.

\section{B. Jenis Data dan Pengumpulannya}

Jenis data yang dikumpulkan antara lain: (1) identitas responden yang meliputi: umur, pendidikan, jumlah anggota keluarga dan mata pencaharian, (2) luas kepemilikan lahan, (3) konsumsi dan harga kayu bakar, (4) konsumsi dan harga minyak tanah dan gas LPG, dan (5) pendapatan rumah tangga pedesaan. Data dikumpulkan dari masing-masing rumah tangga contoh melalui wawancara dalam bentuk kuesioner dan pengecekan langsung sumber informasi yang disampaikan, antara lain: stok kayu bakar, minyak tanah dan gas LPG serta peralatan dan harga masing-masing energi di warung atau pasar. Total rumah tangga contoh yang dipilih sebanyak 259 responden: 94 responden di desa contoh Kabupaten Banjarnegara, 81 responden di desa contoh Kabupaten Sukabumi, dan 84 responden di desa contoh Kabupaten Lebak.

\section{Pengolahan dan Analisis Data}

Data diolah dan disajikan dalam bentuk tabulasi, antara lain: (1) konsumsi dan harga kayu bakar, (2) konsumsi dan harga minyak tanah dan gas LPG, (3) pendapatan rumah tangga, dan (4) asal perolehan kayu bakar. Pengujian faktor-faktor yang mempengaruhi konsumsi kayu bakar menggunakan model ekonometrika persamaan tunggal, dituliskan:

$$
\begin{gathered}
\mathrm{KKB}_{\mathrm{t}}=\mathrm{b}_{0}+\mathrm{b}_{1} \mathrm{HKB}_{\mathrm{t}}+\mathrm{b}_{2} \mathrm{HMT}_{\mathrm{t}}+\mathrm{b}_{3} \mathrm{HLPG}_{\mathrm{t}}+ \\
\mathrm{b}_{4} \mathrm{PRT}_{\mathrm{t}}+\mathrm{b}_{5} \mathrm{UMR}+\mathrm{b}_{6} \mathrm{DPD}_{\mathrm{t}}+\mathrm{b}_{7} \mathrm{DPD}_{\mathrm{t}}+\mathrm{b}_{8} \\
\mathrm{DPK}_{\mathrm{t}}+\mathrm{b}_{9} \mathrm{JAK}+\mathrm{b}_{10} \mathrm{LKL}_{\mathrm{t}}+\mathrm{u}_{\mathrm{t}}
\end{gathered}
$$

di mana

$\mathrm{KKB}=$ Logaritma Natural dari Jumlah Konsumsi Kayu Bakar

$\mathrm{HKB}=$ Logaritma Natural dari Harga Kayu Bakar

HMT = Logaritma Natural dari Harga Minyak Tanah

HLPG $=$ Logaritma Natural dari Harga LPG

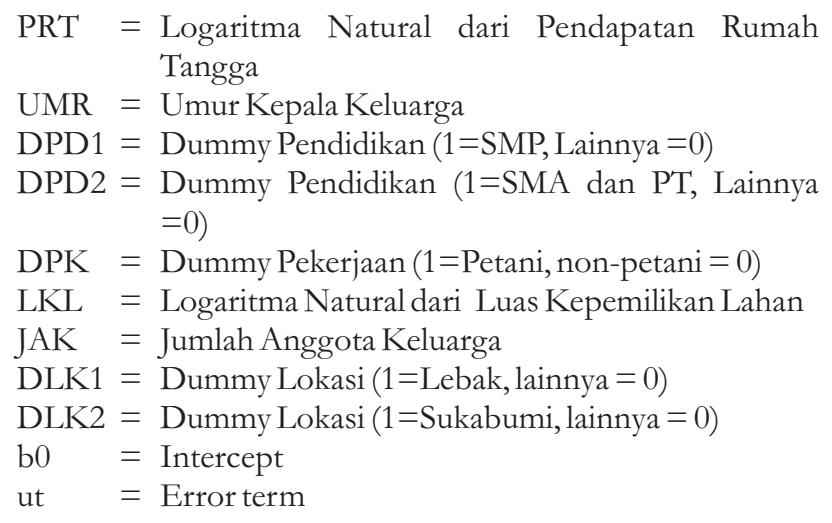

Hipotesis:

$\mathrm{b}_{1}, \mathrm{~b}_{4}<0 ; \mathrm{b}_{2}, \mathrm{~b}_{3}, \mathrm{~b}_{9}, \mathrm{~b}_{10}>0$.

Peubah dummy adalah peubah buatan yang ditetapkan bernilai satu ketika peristiwa yang mewakili terjadi dan nol jika tidak terjadi (Kennedy, 1994). Pemilihan peubah terbaik yang masuk ke dalam model dilakukan dengan menggunakan metode step-wise (Dillon dan Glogstein, 1984).

\section{HASIL DAN PEMBAHASAN}

\section{A. Konsumsi Kayu Bakar Rumah Tangga Pedesaan}

Hasil penelitian menunjukkan bahwa selain mengkonsumsi kayu bakar, rumah tangga pedesaan dari tiga kabupaten contoh juga mengkonsumsi minyak tanah dan gas LPG untuk memasak. Jumlah rumah tangga per desa yang tidak mengkonsumsi kayu bakar adalah 13\%, dan yang hanya mengkonsumsi kayu bakar, 30\% (Tabel 1). Jumlah rumah tangga per desa yang mengkonsumsi minyak tanah adalah 44\% (Tabel 2), dan yang mengkonsumsi gas-LPG, 43\% (Tabel 3). Jumlah rumah tangga per desa yang secara simultan mengonsumsi kayu bakar dan minyak tanah adalah $26 \%$, kayu bakar dan gas LPG, 22\%, dan kayu bakar, minyak tanah dan gas LPG, 12\% (Tabel 4).

Besarnya konsumsi kayu bakar bulanan rumah tangga pedesaan bervariasi. Dari tiga kabupaten contoh, konsumsi kayu bakar tertinggi adalah konsumsi kayu bakar rumah tangga desa contoh Kabupaten Sukabumi (256 kg/bulan), kemudian disusul oleh desa contoh Kabupaten Banjarnegara (206 kg/bulan) dan desa contoh Kabupaten Lebak (165 kg/bulan) (Tabel 5). Variasi konsumsi yang terjadi diduga disebabkan oleh pendapatan, harga 
Tabel 1. Jumlah rumah tangga pedesaan yang tidak dan yang hanya mengonsumsi kayu bakar

Table 1. Number of rural households not consuming and rural households consuming fuelwood)

\begin{tabular}{|c|c|c|c|c|c|c|}
\hline \multirow[t]{2}{*}{$\begin{array}{c}\text { Contoh kabupaten/ } \\
\text { kecamatan (Sample } \\
\text { district/subdistrict) }\end{array}$} & \multirow[t]{2}{*}{$\begin{array}{l}\text { Contoh desa } \\
\text { (Sample village) }\end{array}$} & \multirow[t]{2}{*}{$\begin{array}{c}\text { Total contoh } \\
\text { rumah tangga } \\
\text { pedesaan } \\
\text { (Total sample } \\
\text { rural } \\
\text { housebolds) }\end{array}$} & \multicolumn{2}{|c|}{$\begin{array}{l}\text { Jumlah rumah tangga } \\
\text { pedesaan yang hanya } \\
\text { mengonsumsi kayu bakar } \\
\text { (Number of rural households } \\
\text { consuming fuelwood only) }\end{array}$} & \multicolumn{2}{|c|}{$\begin{array}{c}\text { Jumlah rumah tangga } \\
\text { pedesaan yang tidak } \\
\text { mengonsumsi kayu bakar } \\
\text { (Number of rural households not } \\
\text { consuming fuelwood) }\end{array}$} \\
\hline & & & $\begin{array}{l}\text { Jumlah } \\
\text { (Number) }\end{array}$ & $\%$ & $\begin{array}{l}\text { Jumlah } \\
\text { (Number) }\end{array}$ & $\%$ \\
\hline \multicolumn{7}{|l|}{ Banjarnegara } \\
\hline \multirow[t]{2}{*}{ Punggelan } & Bondolharjo & 24 & 0 & 0 & 2 & 8 \\
\hline & Karangsari & 26 & 8 & 31 & 3 & 12 \\
\hline Banjarmangu & Pekandangan & 44 & 4 & 9 & 6 & 14 \\
\hline \multicolumn{7}{|l|}{ Sukabumi } \\
\hline \multirow[t]{2}{*}{ Jampang Tengah } & Sindangresmi & 33 & 8 & 24 & 5 & 15 \\
\hline & Padabeunghar & 48 & 14 & 29 & 5 & 10 \\
\hline \multicolumn{7}{|l|}{ Lebak } \\
\hline \multirow[t]{2}{*}{ Rangkas Bitung } & $\begin{array}{l}\text { Rangkas Bitung } \\
\text { Timur }\end{array}$ & 45 & 25 & 56 & 6 & 13 \\
\hline & Jatimulya & 39 & 24 & 62 & 8 & 21 \\
\hline Rataan (Average) & & 37 & 12 & 30 & 5 & 13 \\
\hline
\end{tabular}

Sumber: Astana, 2009 (diolah)

Source: Astana, 2009 (treated)

Tabel 2. Jumlah rumah tangga pedesaan yang mengonsumsi minyak tanah

Table 2. Number of rural households consuming kerosene

\begin{tabular}{|c|c|c|c|c|}
\hline \multirow[t]{2}{*}{$\begin{array}{l}\text { Contoh kabupaten/ kecamatan } \\
\text { (Sample district/subdistrict) }\end{array}$} & \multirow[t]{2}{*}{$\begin{array}{l}\text { Contoh desa } \\
\text { (Sample village) }\end{array}$} & \multirow[t]{2}{*}{$\begin{array}{l}\text { Total contoh rumah } \\
\text { tangga pedesaan } \\
\text { (Total sample rural } \\
\text { housebolds) }\end{array}$} & \multicolumn{2}{|c|}{$\begin{array}{c}\text { Jumlah rumah tangga pedesaan } \\
\text { yang mengonsumsi minyak tanah } \\
\text { (Number of rural households consuming } \\
\text { kerosene) }\end{array}$} \\
\hline & & & Jumlah (Number) & $\%$ \\
\hline \multicolumn{5}{|l|}{ Banjarnegara } \\
\hline \multirow[t]{2}{*}{ Punggelan } & Bondolharjo & 24 & 20 & 83 \\
\hline & Karangsari & 26 & 18 & 69 \\
\hline Banjarmangu & Pekandangan & 44 & 31 & 70 \\
\hline Rataan (Average) & & 31 & 23 & 74 \\
\hline \multicolumn{5}{|l|}{ Sukabumi } \\
\hline \multirow[t]{2}{*}{ Jampang Tengah } & Sindangresmi & 33 & 5 & 15 \\
\hline & Padabeunghar & 48 & 25 & 52 \\
\hline Rataan (Average) & & 41 & 15 & 34 \\
\hline \multicolumn{5}{|l|}{ Lebak } \\
\hline \multirow[t]{2}{*}{ Rangkas Bitung } & Rangkas Bitung Timur & 45 & 3 & 7 \\
\hline & Jatimulya & 39 & 5 & 13 \\
\hline Rataan (Average) & & 42 & 4 & 10 \\
\hline Rataan (Average) & & 37 & 15 & 44 \\
\hline
\end{tabular}

Sumber : Astana, 2009 (diolah)

Source : Astana, 2009 (treated)

kayu bakar, dan harga barang substitusi atau komplemen. Pendapatan rumah tangga mempengaruhi konsumsi kayu bakar. Semakin tinggi pendapatan, umumnya mendorong kegiatan memasak menjadi semakin tinggi, yang menyebabkan kebutuhan energi semakin tinggi, 
Tabel 3. Jumlah rumah tangga pedesaan yang mengonsumsi gas LPG

Table 3. Number of rural households consuming gas LPG

\begin{tabular}{|c|c|c|c|c|}
\hline \multirow[t]{2}{*}{$\begin{array}{c}\text { Contoh kabupaten/ } \\
\text { kecamatan (Sample } \\
\text { district/subdistrict) }\end{array}$} & \multirow[t]{2}{*}{$\begin{array}{c}\text { Contoh desa } \\
\text { (Sample village) }\end{array}$} & \multirow[t]{2}{*}{$\begin{array}{l}\text { Total contoh rumah } \\
\text { tangga pedesaan } \\
\text { (Total sample rural } \\
\text { bouseholds) }\end{array}$} & \multicolumn{2}{|c|}{$\begin{array}{l}\text { Jumlah rumah tangga pedesaan } \\
\text { yang mengonsumsi gas LPG } \\
\text { (Number of rural boiseholds } \\
\text { consuming gas LPG) }\end{array}$} \\
\hline & & & Jumlah (Number) & $\%$ \\
\hline \multicolumn{5}{|l|}{ Banjarnegara } \\
\hline \multirow[t]{2}{*}{ Punggelan } & Bondolharjo & 24 & 9 & 38 \\
\hline & Karangsari & 26 & 7 & 27 \\
\hline Banjarmangu & Pekandangan & 44 & 18 & 41 \\
\hline Rataan (Average) & & 31 & 11 & 35 \\
\hline \multicolumn{5}{|l|}{ Sukabumi } \\
\hline \multirow[t]{2}{*}{ Jampang Tengah } & Sindangresmi & 33 & 24 & 73 \\
\hline & Padabeunghar & 48 & 22 & 46 \\
\hline Rataan (Average) & & 41 & 23 & 60 \\
\hline \multicolumn{5}{|l|}{ Lebak } \\
\hline \multirow[t]{2}{*}{ Rangkas Bitung } & Rangkas Bitung Timur & 45 & 19 & 42 \\
\hline & Jatimulya & 39 & 12 & 31 \\
\hline Rataan (Average) & & 42 & 16 & 37 \\
\hline Rataan (Average) & & 37 & 16 & 43 \\
\hline
\end{tabular}

Sumber: Astana, 2009 (diolah)

Source: Astana, 2009 (treated)

Tabel 4. Jumlah rumah tangga pedesaan secara simultan mengonsumsi kayu bakar, minyak tanah dan gas LPG Table 4. Number of rural households simultaneously consuming fuelwood, kerosene and LPG

\begin{tabular}{|c|c|c|c|c|c|c|c|c|}
\hline \multirow{3}{*}{$\begin{array}{l}\text { Contoh } \\
\text { kabupaten/ } \\
\text { kecamatan (Sample } \\
\text { district/subdistrict) }\end{array}$} & \multirow{3}{*}{$\begin{array}{l}\text { Contoh desa } \\
\text { (Sample village) }\end{array}$} & \multirow{3}{*}{$\begin{array}{l}\text { Total contoh } \\
\text { rumah tangga } \\
\text { pedesaan } \\
\text { (Total sample } \\
\text { rural } \\
\text { bouseholds) }\end{array}$} & \multicolumn{6}{|c|}{$\begin{array}{c}\text { Jumlah rumah tangga pedesaan yang secara simultan } \\
\text { mengonsumsi kayu bakar, minyak tanah dan gas LPG } \\
\text { (Number of rural households simultaneously consuming fuetwood, } \\
\text { kerosene and gas LPG) }\end{array}$} \\
\hline & & & \multicolumn{2}{|c|}{$\begin{array}{l}\text { Kayu bakar } \\
\text { (fuelwood) \& } \\
\text { Minyak Tanah } \\
\text { (kerosene) }\end{array}$} & \multicolumn{2}{|c|}{$\begin{array}{c}\text { Kayu bakar } \\
\text { (fuelwood) \& gas } \\
\text { LPG (LPG) }\end{array}$} & \multicolumn{2}{|c|}{$\begin{array}{l}\text { Kayu bakar (fuel- } \\
\text { wood), minyak } \\
\text { tanah (kerosene) \& } \\
\text { gas LPG (LPG) }\end{array}$} \\
\hline & & & $\begin{array}{l}\text { Jumlah } \\
\text { (Number) }\end{array}$ & $\%$ & $\begin{array}{l}\text { Jumlah } \\
\text { (Number) }\end{array}$ & $\%$ & $\begin{array}{l}\text { Jumlah } \\
\text { (Number) }\end{array}$ & $\%$ \\
\hline \multicolumn{9}{|l|}{ Banjarnegara } \\
\hline \multirow[t]{2}{*}{ Punggelan } & Bondolharjo & 24 & 13 & 54 & 4 & 17 & 5 & 21 \\
\hline & Karangsari & 26 & 11 & 42 & 1 & 4 & 3 & 12 \\
\hline Banjarmangu & Pekandangan & 44 & 21 & 48 & 10 & 23 & 5 & 11 \\
\hline Rataan (Average) & & 31 & 15 & 48 & 5 & 15 & 4 & 15 \\
\hline \multicolumn{9}{|l|}{ Sukabumi } \\
\hline \multirow[t]{2}{*}{ Jampang Tengah } & Sindangresmi & 33 & 1 & 3 & 17 & 52 & 4 & 12 \\
\hline & Padabeunghar & 48 & 12 & 25 & 8 & 17 & 10 & 21 \\
\hline Rataan (Average) & & 41 & 7 & 14 & 13 & 35 & 7 & 17 \\
\hline \multicolumn{9}{|l|}{ Lebak } \\
\hline $\begin{array}{r}\text { Rangkas } \\
\text { Bitung }\end{array}$ & $\begin{array}{l}\text { Rangkas Bitung } \\
\text { Timur }\end{array}$ & 45 & 1 & 2 & 16 & 36 & 2 & 4 \\
\hline & Jatimulya & 39 & 3 & 8 & 4 & 10 & 0 & 0 \\
\hline $\begin{array}{r}\text { Rataan } \\
\text { (Average) }\end{array}$ & & 42 & 2 & 5 & 10 & 23 & 1 & 2 \\
\hline Rataan (Average) & & 37 & 9 & 26 & 9 & 22 & 4 & 12 \\
\hline
\end{tabular}

Sumber : Astana, 2009 (diolah)

Source : Astana, 2009 (treated) 
Tabel 5. Konsumsi kayu bakar rumah tangga pedesaan

Table 5. Fuelwood consumption of rural housebolds

\begin{tabular}{|c|c|c|c|c|}
\hline \multirow[t]{2}{*}{$\begin{array}{c}\text { Contoh kabupaten/ kecamatan (Sample } \\
\text { district/subdistrict) }\end{array}$} & \multirow[t]{2}{*}{$\begin{array}{c}\text { Contoh desa } \\
\text { village })\end{array} \quad$ (Sample } & \multicolumn{3}{|c|}{$\begin{array}{l}\text { Konsumsi kayu bakar rumah tangga } \\
\text { pedesaan (Fuelwood consumption of rural } \\
\text { households) (kgs/bulan/month) }\end{array}$} \\
\hline & & $\begin{array}{l}\text { Tertinggi } \\
\text { (Highest) }\end{array}$ & $\begin{array}{c}\text { Terendah } \\
\text { (Lowest) }\end{array}$ & $\begin{array}{l}\text { Rataan } \\
\text { (Average) }\end{array}$ \\
\hline Banjarnegara & & 1050 & 18 & 206 \\
\hline Punggelan & Bondolharjo & 1050 & 18 & 366 \\
\hline & Karangsari & 438 & 88 & 185 \\
\hline Banjarmangu & Pekandangan & 320 & 35 & 126 \\
\hline Sukabumi & & 2250 & 20 & 256 \\
\hline Jampang Tengah & Sindangresmi & 2250 & 20 & 252 \\
\hline & Padabeunghar & 800 & 50 & 252 \\
\hline Lebak & & 480 & 48 & 165 \\
\hline Rangkas Bitung & Rangkas Bitung Timur & 280 & 60 & 165 \\
\hline & Jatimulya & 480 & 48 & 171 \\
\hline Tiga kabupaten (Three districts) & & 2250 & 18 & 208 \\
\hline
\end{tabular}

Sumber: Astana, 2009 (treated)

Source: Astana, 2009 (treated)

Tabel 6. Harga kayu bakar yang dikonsumsi rumah tangga pedesaan

Table 6. Price of fuelwood consumed by rural households

\begin{tabular}{|c|c|c|c|c|}
\hline \multirow[t]{2}{*}{$\begin{array}{c}\text { Contoh kabupaten/ kecamatan (Sample } \\
\text { district/subdistrict) }\end{array}$} & \multirow[t]{2}{*}{$\begin{array}{l}\text { Contoh desa } \\
\text { (Sample village) }\end{array}$} & \multicolumn{3}{|c|}{$\begin{array}{c}\text { Harga kayu bakar rumah tangga pedesaan } \\
\text { (Price of fuelwood consumed by rural households) } \\
(\mathrm{Rp} / \mathrm{kg})\end{array}$} \\
\hline & & $\begin{array}{l}\text { Tertinggi } \\
\text { (Highest) }\end{array}$ & $\begin{array}{l}\text { Terendah } \\
\text { (Lowest) }\end{array}$ & $\begin{array}{l}\text { Rataan } \\
\text { (Average) }\end{array}$ \\
\hline Banjarnegara & & 1143 & 857 & 984 \\
\hline Punggelan & Bondolharjo & 1143 & 857 & 1000 \\
\hline & Karangsari & 857 & 857 & 857 \\
\hline Banjarmangu & Pekandangan & 1143 & 857 & 1000 \\
\hline Sukabumi & & 300 & 300 & 300 \\
\hline Jampang Tengah & Sindangresmi & 300 & 300 & 300 \\
\hline & Padabeunghar & - & - & - \\
\hline Lebak & & 1125 & 500 & 625 \\
\hline Rangkas Bitung & Rangkas Bitung Timur & 625 & 500 & 525 \\
\hline & Jatimulya & 1125 & 1125 & 1125 \\
\hline Tiga kabupaten (Three districts) & & 1143 & 300 & 807 \\
\hline
\end{tabular}

Sumber : Astana, 2009 (diolah)

Source : Astana, 2009 (treated)

meskipun konsumsi kayu bakar dapat menurun. Konsumsi kayu bakar juga dipengaruhi oleh harganya. Semakin tinggi harga semakin rendah konsumsinya. Demikian pula dengan harga barang lain, seperti harga minyak tanah dan gas LPG apakah berperan sebagai barang substitusi atau komplemen juga dapat mempengaruhi. Harga kayu bakar di desa contoh Kabupaten Sukabumi (Rp 300/kg) relatif lebih rendah dibanding di desa contoh Kabupaten Banjarnegara 
(Rp 984/kg) dan Lebak (Rp 625/kg) (Tabel 6). Ini mengindikasikan antara konsumsi dan harga kayu bakar memiliki hubungan fungsional yang negatif selama konsumsi kayu bakar di desa contoh Kabupaten Sukabumi cenderung lebih tinggi dibanding di desa contoh Kabupaten Banjarnegara dan Lebak (Tabel 5). Sebaliknya pendapatan rumah tangga desa contoh Kabupaten Banjarnegara (Rp 1 993 987/bulan) dan Sukabumi (Rp 1097 $840 /$ bulan) relatif lebih tinggi dibanding desa contoh Kabupaten Lebak (Rp 736 786/bulan) (Tabel 7 dan Tabel 8). Ini mengidikasikan antara konsumsi kayu bakar dan pendapatan memiliki hubungan fungsional yang positif. Namun pendapatan yang tinggi juga dapat mengindikasikan konsumsi minyak tanah yang tinggi, sehingga antara pendapatan dan konsumsi kayu bakar dapat memiliki hubungan fungsional negatif: semakin tinggi pendapatan semakin rendah kayu bakar yang dikonsumsi.

Harga minyak tanah mempengaruhi konsumsi kayu bakar karena perubahan harga minyak tanah mempengaruhi konsumsinya, yang akhirnya mempengaruhi konsumsi kayu bakar. Konsumsi minyak tanah bulanan rumah tangga pedesaan di desa contoh Kabupaten Sukabumi adalah tertinggi
(9,3 liter/bulan), kemudian disusul oleh desa contoh Kabupaten Lebak (8,4 liter/bulan), dan terendah adalah desa contoh Kabupaten Banjarnegera (5.8 liter/bulan) (Tabel 9). Seperti harga minyak tanah, harga gas LPG juga mempengaruhi konsumsi kayu bakar. Konsumsi gas LPG bulanan rumah tangga pedesaan di desa contoh Kabupaten Lebak adalah tertinggi (7,3 $\mathrm{kg}$ /bulan), kemudian disusul oleh desa contoh Kabupaten Sukabumi (6,9 kg/bulan), dan terendah adalah rumah tangga desa contoh Kabupaten Banjarnegara (6,2 kg/bulan) (Tabel 10).

Harga minyak tanah di desa contoh Kabupaten Sukabumi (Rp 9000/liter) dan Lebak (Rp 8063/liter) lebih tinggi dibanding desa contoh Kabupaten Banjarnegara (Rp 4724/liter) (Tabel 11). Ini mengindikasikan bahwa harga minyak tanah di desa contoh cenderung berpengaruh negatif terhadap konsumsi kayu bakar selama konsumsi kayu bakar di desa contoh Kabupaten Lebak cenderung lebih rendah dibanding di desa contoh Kabupaten Banjarnegara, meskipun untuk memastikan dengan memasukkan desa contoh Kabupaten Sukabumi memerlukan suatu pengujian statistik. Jika benar demikian, maka minyak tanah cenderung sebagai barang

Tabel 7. Pendapatan per bulan rumah tangga pedesaan

Table 7. Average monthly income of rural households

\begin{tabular}{|c|c|c|c|c|}
\hline \multirow[t]{2}{*}{$\begin{array}{l}\text { Contoh kabupaten/ } \\
\text { kecamatan (Sample } \\
\text { district/subdistrict) }\end{array}$} & \multirow[t]{2}{*}{$\begin{array}{l}\text { Contoh desa } \\
\text { (Sample village) }\end{array}$} & \multirow[t]{2}{*}{$\begin{array}{c}\text { Total contoh rumah } \\
\text { tangga pedesaan } \\
\text { (Total sample rural } \\
\text { households) }\end{array}$} & \multicolumn{2}{|c|}{$\begin{array}{c}\text { Pendapatan per bulan rumah tangga } \\
\text { pedesaan (Average monthly income of rural } \\
\text { households) (Rp/bulan/month) }\end{array}$} \\
\hline & & & Kisaran (Range) & $\begin{array}{l}\text { Rataan } \\
\text { (Average) }\end{array}$ \\
\hline Banjarnegara & & 94 & $65000-10000000$ & 1993987 \\
\hline Punggelan & Bondolharjo & 24 & $300000-4000000$ & 1654167 \\
\hline & Karangsari & 26 & $150000-3500000$ & 1294231 \\
\hline Banjarmangu & Pekandangan & 44 & $65000-10000000$ & 2592841 \\
\hline Sukabumi & & 81 & $190000-6000000$ & 1097840 \\
\hline Jampang Tengah & Sindangresmi & 33 & $220000-3000000$ & 1198636 \\
\hline & Padabeunghar & 48 & $190000-6000000$ & 1028542 \\
\hline Lebak & & 84 & $200000-3750000$ & 736786 \\
\hline Rangkas Bitung & Rangkas Bitung Timur & 45 & $200000-1700000$ & 592000 \\
\hline & Jatimulya & 39 & $250000-3750000$ & 903846 \\
\hline $\begin{array}{l}\text { Tiga kabupaten (Three } \\
\text { districts) }\end{array}$ & & 259 & $65000-10000000$ & 1313281 \\
\hline
\end{tabular}

Sumber : Astana, 2009 (diolah)

Source : Astana, 2009 (treated) 
Tabel 8. Jumlah rumah tangga pedesaan menurut pendapatan per bulan

Table 8. Number of rural households according to monthly income

\begin{tabular}{|c|c|c|c|c|}
\hline \multirow{2}{*}{$\begin{array}{c}\text { Contoh kabupaten/ } \\
\text { kecamatan (Sample } \\
\text { district/subdistrict) }\end{array}$} & \multirow{2}{*}{$\begin{array}{l}\text { Contoh desa } \\
\text { (Sample village) }\end{array}$} & \multicolumn{3}{|c|}{$\begin{array}{l}\text { Jumlah rumah tangga pedesaan menurut pendapatan per } \\
\text { bulan (Number of rural households according to monthly income) }\end{array}$} \\
\hline & & $\begin{array}{l}\text { Di atas } \\
\text { (Above) Rp } 1 \\
\text { juta/million }\end{array}$ & $\begin{array}{l}\text { Antara (Between) } \\
\text { Rp } 500 \text { ribu } \\
\text { (thousand) dan (and) } \\
\text { Rp } 1 \text { juta/ million }\end{array}$ & $\begin{array}{l}\text { Di bawah (Under) } \\
\text { Rp } 500 \\
\text { ribu/thounsand) }\end{array}$ \\
\hline \multicolumn{5}{|l|}{ Banjarnegara } \\
\hline \multirow[t]{2}{*}{ Punggelan } & Bondolharjo & $14(58 \%)$ & $7(29 \%)$ & $3(13 \%)$ \\
\hline & Karangsari & $14(54 \%)$ & $5(19 \%)$ & $7(27 \%)$ \\
\hline Banjarmangu & Pekandangan & $30(68 \%)$ & $3(7 \%)$ & $11(25 \%)$ \\
\hline Rataan (Average) & & $19(62 \%)$ & $5(16 \%)$ & $7(22 \%)$ \\
\hline \multicolumn{5}{|l|}{ Sukabumi } \\
\hline \multirow[t]{2}{*}{ Jampang Tengah } & Sindangresmi & $17(52 \%)$ & $12(36 \%)$ & $4(12 \%)$ \\
\hline & Padabeunghar & $13(27 \%)$ & $15(31 \%)$ & $20(42 \%)$ \\
\hline Rataan (Average) & & $15(37 \%)$ & $14(33 \%)$ & $12(30 \%)$ \\
\hline \multicolumn{5}{|l|}{ Lebak } \\
\hline Rangkas Bitung & Rangkas Bitung Timur & $5(11 \%)$ & $20(44 \%)$ & $20(44 \%)$ \\
\hline & Jatimulya & $12(31 \%)$ & $9(23 \%)$ & $18(46 \%)$ \\
\hline Rataan (Average) & & $9(20 \%)$ & $15(35 \%)$ & $19(45 \%)$ \\
\hline Rataan (Average) & & $15(43 \%)$ & $10(27 \%)$ & $12(30 \%)$ \\
\hline
\end{tabular}

Sumber : Astana, 2009 (diolah)

Source : Astana, 2009 (treated)

Tabel 9. Konsumsi minyak tanah rumah tangga pedesaan

Table 9. Kerosene consumption of rural households)

\begin{tabular}{|c|c|c|c|c|}
\hline \multirow[t]{2}{*}{$\begin{array}{l}\text { Contoh kabupaten/ kecamatan (Sample } \\
\text { district/subdistrict) }\end{array}$} & \multirow[t]{2}{*}{$\begin{array}{l}\text { Contoh desa } \\
\text { (Sample village) }\end{array}$} & \multicolumn{3}{|c|}{$\begin{array}{c}\text { Konsumsi minyak tanah rumah tangga } \\
\text { pedesaan Kerosene consumption of rural households } \\
\text { (liter/bulan/month) }\end{array}$} \\
\hline & & $\begin{array}{l}\text { Tertinggi } \\
\text { (Highest) }\end{array}$ & $\begin{array}{l}\text { Terendah } \\
\text { (Lowest) }\end{array}$ & $\begin{array}{c}\text { Rataan } \\
(\text { Average })\end{array}$ \\
\hline Banjarnegara & & 30 & 1 & 5.8 \\
\hline Punggelan & Bondolharjo & 30 & 2 & 7.3 \\
\hline & Karangsari & 10 & 2 & 4.4 \\
\hline Banjarmangu & Pekandangan & 30 & 1 & 5.6 \\
\hline Sukabumi & & 30 & 1 & 9.3 \\
\hline Jampang Tengah & Sindangresmi & 20 & 1 & 6.6 \\
\hline & Padabeunghar & 30 & 1 & 10.1 \\
\hline Lebak & & 20 & 2 & 8.4 \\
\hline Rangkas Bitung & Rangkas Bitung Timur & 10 & 2 & 5.3 \\
\hline & Jatimulya & 20 & 5 & 10.8 \\
\hline Tiga kabupaten (Three districts) & & 30 & 1 & 7.0 \\
\hline
\end{tabular}

Sumber : Astana, 2009 (diolah)

Source : Astana, 2009 (treated)

komplemen daripada sebagai barang substitusi kayu bakar. Sedangkan harga gas LPG di desa contoh Kabupaten Banjarnegara (Rp 6944/kg) dan
Sukabumi (Rp 5190/kg) lebih tinggi dibandingkan desa contoh Kabupaten Lebak (Rp 4823/kg) (Tabel 12). Ini mengindikasikan bahwa harga gas 
LPG di desa contoh cenderung berpengaruh positif terhadap konsumsi kayu bakar selama konsumsi kayu bakar di desa contoh Kabupaten Lebak cenderung lebih rendah dibanding di desa contoh Kabupaten Banjarnegara dan Sukabumi. Jika benar demikian, gas LPG cenderung sebagai barang substitusi daripada sebagai barang komplemen kayu bakar.

Tabel 10. Konsumsi gas-LPG rumah tangga pedesaan

Table 10. Gas LPG consumption of rural households

\begin{tabular}{|c|c|c|c|c|}
\hline \multirow[t]{2}{*}{$\begin{array}{c}\text { Contoh kabupaten/ kecamatan (Sample } \\
\text { district/subdistrict) }\end{array}$} & \multirow[t]{2}{*}{$\begin{array}{l}\text { Contoh desa } \\
\text { (Sample village) }\end{array}$} & \multicolumn{3}{|c|}{$\begin{array}{l}\text { Konsumsi gas-LPG rumah tangga pedesaan } \\
\text { (Gas LPG consumption of rural households) } \\
\text { (kg/bulan/month) }\end{array}$} \\
\hline & & $\begin{array}{l}\text { Tertinggi } \\
\text { (Highest) }\end{array}$ & $\begin{array}{c}\text { Terendah } \\
\text { (Lowest) }\end{array}$ & $\begin{array}{l}\text { Rataan } \\
\text { (Average) }\end{array}$ \\
\hline Banjarnegara & & 12 & 2.4 & 6.2 \\
\hline Punggelan & Bondolharjo & 12 & 6 & 8.5 \\
\hline & Karangsari & 6 & 3 & 3.4 \\
\hline Banjarmangu & Pekandangan & 12 & 2.4 & 6.5 \\
\hline Sukabumi & & & & 6.9 \\
\hline Jampang Tengah & Sindangresmi & 12 & 0.75 & 6.7 \\
\hline & Padabeunghar & 12 & 3 & 7.2 \\
\hline Lebak & & 24 & 0.75 & 7.3 \\
\hline Rangkas Bitung & Rangkas Bitung Timur & 9 & 0.75 & 3.2 \\
\hline & Jatimulya & 24 & 9 & 13.8 \\
\hline Tiga kabupaten (Three districts) & & 24 & 0.75 & 6.8 \\
\hline
\end{tabular}

Sumber : Astana, 2009 (diolah)

Source : Astana, 2009 (treated)

Tabel 11. Harga minyak tanah rumah tangga pedesaan

Table 11. Price of kerosene consumed by rural households

\begin{tabular}{|c|c|c|c|c|}
\hline \multirow[t]{2}{*}{$\begin{array}{c}\text { Contoh kabupaten/ kecamatan (Sample } \\
\text { district/subdistrict) }\end{array}$} & \multirow[t]{2}{*}{$\begin{array}{l}\text { Contoh desa } \\
\text { (Sample village) }\end{array}$} & \multicolumn{3}{|c|}{$\begin{array}{c}\text { Harga minyak tanah rumah tangga pedesaan } \\
\text { (Price of kerosene consumed by ruralhouseholds) } \\
\text { (Rp/liter) }\end{array}$} \\
\hline & & $\begin{array}{l}\text { Tertinggi } \\
\text { (Highest) }\end{array}$ & $\begin{array}{c}\text { Terendah } \\
\text { (Lowest) }\end{array}$ & $\begin{array}{l}\text { Rataan } \\
(\text { Average })\end{array}$ \\
\hline Banjarnegara & & 6000 & 4000 & 4724 \\
\hline Punggelan & Bondolharjo & 5000 & 4000 & 4250 \\
\hline & Karangsari & 4500 & 4000 & 4206 \\
\hline Banjarmangu & Pekandangan & 6000 & 4000 & 5333 \\
\hline Sukabumi & & 10000 & 7000 & 9000 \\
\hline Jampang Tengah & Sindangresmi & 10000 & 9000 & 9200 \\
\hline & Padabeunghar & 10000 & 7000 & 8960 \\
\hline Lebak & & 8500 & 7500 & 8063 \\
\hline Rangkas Bitung & Rangkas Bitung Timur & 8000 & 7500 & 7667 \\
\hline & Jatimulya & 8500 & 8000 & 8300 \\
\hline Tiga kabupaten (Three districts) & & 10000 & 4000 & 6200 \\
\hline
\end{tabular}

Sumber : Astana, 2009 (diolah)

Source: Astana, 2009 (treated) 
Hasil penelitian juga menunjukkan bahwa kayu bakar yang dikonsumsi oleh rumah tangga pedesaan di tiga kabupaten contoh berasal dari kebun (hutan rakyat). Dari tiga kabupaten contoh, jumlah rumah tangga per desa yang memungut kayu bakar di kebun adalah 93\% dan yang membeli

Tabel 12. Harga gas LPG rumah tangga pedesaan

Table 12. Price of gas LPG consumed by rural households

\begin{tabular}{|c|c|c|c|c|}
\hline \multirow[t]{2}{*}{$\begin{array}{l}\text { Contoh kabupaten/ kecamatan (Sample } \\
\text { district/subdistrict) }\end{array}$} & \multirow{2}{*}{$\begin{array}{l}\text { Contoh desa } \\
\text { (Sample village) }\end{array}$} & \multicolumn{3}{|c|}{$\begin{array}{l}\text { Harga gas-LPG rumah tangga pedesaan (Price } \\
\text { of gas } L P G \text { consumed by rural households) }(\mathrm{Rp} / \mathrm{kg})\end{array}$} \\
\hline & & $\begin{array}{l}\text { Tertinggi } \\
\text { (Highest) }\end{array}$ & $\begin{array}{l}\text { Terendah } \\
\text { (Lowest) }\end{array}$ & $\begin{array}{l}\text { Rataan } \\
(\text { Average })\end{array}$ \\
\hline Banjarnegara & & 7500 & 6250 & 6944 \\
\hline Punggelan & Bondolharjo & 7500 & 6250 & 6958 \\
\hline & Karangsari & 7083 & 6917 & 7060 \\
\hline Banjarmangu & Pekandangan & 7083 & 6667 & 6969 \\
\hline Sukabumi & & 7083 & 4333 & 5190 \\
\hline Jampang Tengah & Sindangresmi & 6000 & 5000 & 5250 \\
\hline & Padabeunghar & 7083 & 4333 & 5125 \\
\hline Lebak & & 5000 & 4667 & 4823 \\
\hline Rangkas Bitung & Rangkas Bitung Timur & 5000 & 4667 & 4772 \\
\hline & Jatimulya & 5000 & 4833 & 4903 \\
\hline Tiga kabupaten (Three districts) & & 7500 & 4333 & 5613 \\
\hline
\end{tabular}

Sumber: Astana, 2009 (diolah)

Source: Astana, 2009 (treated)

Tabel 13. Asal kayu bakar yang dikonsumsi rumah tangga pedesaan

Table 13. Origin of fuelwood consumed by rural households)

\begin{tabular}{|c|c|c|c|}
\hline \multirow[t]{2}{*}{$\begin{array}{l}\text { Contoh kabupaten/ } \\
\text { kecamatan (Sample } \\
\text { district/subdistrict) }\end{array}$} & \multirow[t]{2}{*}{$\begin{array}{l}\text { Contoh desa } \\
\text { (Sample village) }\end{array}$} & \multicolumn{2}{|c|}{$\begin{array}{l}\text { Jumlah contoh rumah tangga menurut asal kayu energi yang } \\
\text { dikonsumsi (Number of sample household according to origin of } \\
\text { fuelwood consumed) }\end{array}$} \\
\hline & & $\begin{array}{l}\text { Memungut di kebun } \\
\text { (Gathering from estates) }\end{array}$ & $\begin{array}{l}\text { Membeli di warung/pasar } \\
\text { (Buying from } \\
\text { "warung/market" }\end{array}$ \\
\hline \multicolumn{4}{|l|}{ Banjarnegara } \\
\hline \multirow[t]{2}{*}{ Punggelan } & Bondolharjo & $18(82 \%)$ & $4(18 \%)$ \\
\hline & Karangsari & $23(96 \%)$ & $1(4 \%)$ \\
\hline Banjarmangu & Pekandangan & $36(90 \%)$ & $4(10 \%)$ \\
\hline Rataan (Average) & & $26(89 \%)$ & $3(11 \%)$ \\
\hline \multicolumn{4}{|l|}{ Sukabumi } \\
\hline \multirow[t]{2}{*}{ Jampang Tengah } & Sindangresmi & $27(96 \%)$ & $1(4 \%)$ \\
\hline & Padabeunghar & $44(100 \%)$ & $0(0 \%)$ \\
\hline Rataan (Average) & & $36(98 \%)$ & $1(2 \%)$ \\
\hline \multicolumn{4}{|l|}{ Lebak } \\
\hline \multirow[t]{2}{*}{ Rangkas Bitung } & Rangkas Bitung Timur & $40(89 \%)$ & $5(11 \%)$ \\
\hline & Jatimulya & $28(97 \%)$ & $1(3 \%)$ \\
\hline Rataan (Average) & & $34(93 \%)$ & $3(7 \%)$ \\
\hline Rataan (Average) & & $31(93 \%)$ & $2(7 \%)$ \\
\hline
\end{tabular}

Sumber: Astana, 2009 (diolah)

Source : Astana, 2009 (treated) 
di warung atau pasar, 7\% (Table 13). Ini menunjukkan bahwa potensi kayu bakar dari kebun kayu atau hutan rakyat adalah tinggi. Hasil observasi lapangan mengkomfirmasi hal tersebut. Tingginya potensi kayu bakar dari kebun rakyat setidaknya disebabkan oleh dua faktor. Pertama, adanya pelaksanaan program penghijauan oleh pemerintah yang dimulai sejak tahun 1970an, terutama di daerah-daerah aliran sungai (DAS) yang dianggap kritis, yang meliputi hutan yang rusak, belukar, padang alang-alang, tanah kosong (gundul) dan tanah terlantar serta tegalan (BPKH, 2009). Kedua, adanya peningkatan permintaan pasar kayu selaras dengan peningkatan per-tumbuhan ekonomi sejak tahun 1980-an. Kedua faktor tersebut mendorong berkembangnya hutan atau kebun kayu rakyat di Jawa, termasuk di tiga kabupaten contoh.

\section{B. Hasil Pengujian Faktor-faktor yang Mempengaruhi Konsumsi Kayu Bakar Rumah Tangga Pedesaan}

Faktor-faktor yang mempengaruhi konsumsi kayu bakar yang diuji adalah harganya, harga barang lain (substitusi atau komplemen), dan pendapatan rumah tangga. Selain beberapa faktor tersebut juga diuji pengaruh peubah lain, yaitu: (1) umur, (2) pendidikan, (3) pekerjaan, (4) luas kepemilikan lahan, (5) jumlah anggota rumah tangga, dan (6) lokasi. Dengan menggunakan metode step-wise, peubah yang terbaik dimasukkan ke dalam model. Pada Tabel 14 terlihat peubah harga gas-LPG secara statistik (metode step-wise) tidak termasuk peubah terbaik, sehingga tidak dimasukkan ke dalam model, meskipun menurut teori, dapat mempengaruhi konsumsi kayu bakar. Demikian pula dengan peubah dummy DPD2 (pendidikan SMA dan perguruan tinggi) dan DLK1 (lokasi Lebak) tidak termasuk peubah terbaik yang dapat dimasukkan ke dalam model.

Hasil pengujian menunjukkan bahwa peubah harga kayu bakar (HKB), harga minyak tanah (HMT) dan pendapatan rumah tangga (PRT) berpengaruh nyata. Peubah harga kayu bakar (HKB), sesuai teori, berpengaruh nyata dengan tanda negatif. Nilai elastisitas harga dari konsumsi kayu bakar adalah - 3,4. Nilai ini mempunyai arti bahwa kenaikan (penurunan) harga kayu bakar sebesar 1\% dapat diharapkan akan menurunkan (menaikkan) konsumsi kayu bakar sebesar 3,4\%. Dengan kata lain, konsumsi kayu bakar peka terhadap perubahan harganya. Peubah pendapatan berpengaruh nyata dengan tanda negatif. Ini menunjukkan bahwa konsumsi kayu bakar rumah tangga pedesaan menurun selaras dengan meningkatnya pendapatan rumah tangga pedesaan. Nilai elastisitas pendapatan dari konsumsi kayu bakar sebesar - 0,89 memiliki arti

Tabel 14. Parameter dugaan model konsumsi kayu bakar rumah tangga pedesaan

Table 14. Parameter estimates of rural households fuelwood consumption model)

\begin{tabular}{crcrc}
\hline \hline Variable & Coefficient & Std. Error & t-Statistic & Prob. \\
\hline \hline PRT & -0.885226 & 0.277650 & -3.188281 & 0.0243 \\
HKB & -3.409591 & 0.591347 & -5.765805 & 0.0022 \\
\hline C & 60.98083 & 11.43279 & 5.333855 & 0.0031 \\
LKL & 0.406000 & 0.132292 & 3.068979 & 0.0278 \\
DPK & -3.958661 & 0.658558 & -6.011101 & 0.0018 \\
JAK & 0.498151 & 0.239469 & 2.080230 & 0.0920 \\
HMT & -2.013243 & 1.129592 & -1.782275 & 0.1348 \\
DLK2 & 1.595987 & 0.767765 & 2.078743 & 0.0922 \\
UMR & 0.053681 & 0.038113 & 1.408463 & 0.2180 \\
DPD1 & 0.367624 & 0.478010 & 0.769073 & 0.4766 \\
\hline \hline R-squared & 0.956462 & Mean dependent var & & 4.893502 \\
Adjusted R-squared & 0.878093 & S.D. dependent var & & 1.164597 \\
S.E. of regression & 0.406621 & Akaike info criterion & & 1.7448882 \\
Sum squared resid & 0.826701 & Schwarz criterion & & 1.267820 \\
Log likelihood & 0.453637 & Hannan-Quinn criter. & & 3.139399 \\
F-statistic & 12.20466 & Durbin-Watson stat & & \\
Prob(F-statistic) & 0.006598 & & & \\
\hline \hline
\end{tabular}


bahwa kenaikan (penurunan) pendapatan sebesar 1\% dapat diharapkan akan menurunkan (menaikkan) konsumsi kayu bakar sebesar 0,89\%. Dengan kata lain, konsumsi kayu bakar tidak peka terhadap perubahan pendapatan rumah tangga pedesaan.

Peubah harga minyak tanah (HMT) menarik untuk dicermati. Pertama, harga minyak tanah berpengaruh nyata dengan tanda negatif. Ini menunjukkan (dalam kasus ini) bahwa minyak tanah bukan merupakan barang substitusi tetapi barang komplemen kayu bakar. Faktanya menunjukkan terdapat rumah tangga pedesaan yang secara simultan mengkonsumsi kayu bakar dan minyak tanah (Tabel 4). Kedua, nilai elastisitas harga minyak tanah adalah - 2,0. Ini memiliki arti bahwa kenaikan (penurunan) harga minyak tanah sebesar 1\% dapat diharapkan akan menurunkan (menaikkan) konsumsi kayu bakar sebesar 2\%, yang berarti konsumsi kayu bakar peka terhadap perubahan harga minyak tanah.

Pada Tabel 14 terlihat peubah dummy pendidikan SMP (DPD1) tidak berpengaruh nyata. Ini menunjukkan bahwa konsumsi kayu bakar tidak berbeda antara rumah tangga pedesaan dengan kepala keluarga berpendidikan (SMP) atau berpendidikan lainnya. Sebaliknya peubah dummy pekerjaan (DPK) berpengaruh nyata dengan tanda negatif. Ini menunjukkan bahwa konsumsi kayu bakar petani lebih rendah dibanding non-petani. Peubah dummy lokasi Sukabumi (DLK2) juga berpengaruh nyata dengan tanda positif, yang menunjukkan konsumsi kayu bakar rumah tangga pedesaan Kabupaten Sukabumi lebih tinggi dibanding kabupaten lain.

Peubah umur (UMR), jumlah anggota rumah tangga (JAK) dan luas kepemilikan lahan ( $\mathrm{LKH})$ juga berpengaruh nyata. Peubah umur berpengaruh nyata dengan tanda positif. Ini menunjukkan bahwa konsumsi kayu bakar lebih tinggi terjadi dalam rumah tangga dengan kepala keluarga yang berumur tua dibanding umur muda. Peubah jumlah anggota keluarga (JAK) juga berpengaruh nyata dengan tanda positif, yang menunjukkan bahwa konsumsi kayu bakar meningkat dengan meningkatnya jumlah anggota keluarga. Pengaruh luas kepemilikan lahan juga bertanda positif, yang menunjukkan bahwa konsumsi kayu bakar juga meningkat dengan semakin luasnya kepemilikan lahan.

\section{KESIMPULAN DAN SARAN}

\section{A. Kesimpulan}

1. Kayu bakar hingga kini masih menjadi andalan masyarakat pedesaan untuk memasak. Jumlah rumah tangga per desa yang tidak mengkonsumsi kayu bakar hanya 13\%. Konsumsi kayu bakar rumah tangga pedesaan berkisar antara 165 - $256 \mathrm{~kg}$ per bulan. Selain mengkonsumsi kayu bakar, rumah tangga pedesaan juga mengkonsumsi minyak tanah dan gas LPG masing-masing berkisar antara 5,8 9,3 liter per bulan dan 6,2 - 7,3 kg per bulan.

2. Tingkat konsumsi kayu bakar di tiga kabupaten contoh tidak menimbulkan tekanan terhadap kelestarian hutan negara sekitar, karena 93\% kayu bakar yang dikonsumsi diperoleh dari areal kebun dan hanya $7 \%$ yang berasal dari pembelian di warung atau pasar.

3. Konsumsi kayu bakar dipengaruhi oleh pendapatan, harga kayu bakar dan harga minyak tanah dengan elastisitas masing-masing dari konsumsi kayu bakar adalah 0.89, -3.4, dan -2.0. Konsumsi kayu bakar rumah tangga dengan kepala keluarga berumur tua lebih tinggi dibanding umur muda, non-petani dibanding petani, dan Kabupaten Sukabumi dibanding Kabupaten Banjarnegara dan Lebak. Konsumsi kayu bakar meningkat dengan meningkatnya jumlah anggota keluarga dan luas kepemilikan lahan.

\section{B. Saran}

1. Fakta bahwa kayu bakar hingga kini masih menjadi andalan masyarakat pedesaan untuk memasak, 93\% konsumsinya berasal dari kebun dan sangat peka terhadap perubahan harganya $(-3,4)$ menyarankan program penghijauan dengan pepohonan penghasil kayu perlu terus dilaksanakan agar pengurangan tekanan konsumsi kayu bakar tersebut terhadap kelestarian hutan negara sekitar secara efektif tetap dapat dipertahankan.

2. Elastisitas pendapatan rumah tangga dan harga minyak tanah yang negatif menyimpulkan bahwa kebijakan pengurangan subsidi harga minyak tanah jika dilaksanakan, apakah akan berdampak negatif atau positif terhadap kelestarian hutan negara sekitar, bergantung 
pada net effect yang ditimbulkan. Namun karena konsumsi kayu bakar lebih peka terhadap perubahan harga minyak tanah $(-2,0)$ dibanding pendapatan rumah tangga $(-0,89)$, dampaknya diprediksi cenderung positif dan karenanya kebijakan antisipatif terhadap dampaknya di tiga kabupaten yang diteliti tidak diperlukan jika kebijakan pengurangan subsidi harga minyak tanah dilaksanakan.

\section{DAFTAR PUSTAKA}

Astana, S. 2009. Laporan Hasil Penelitian I: FaktorFaktor yang mempengaruhi konsumsi kayu energi rumah tangga pedesaan kasus Banjarnegara. Pusat Penelitian Sosial Ekonomi dan Kebijakan Kehutanan, Bogor.

Astana, S. 2009. Laporan Hasil Penelitian II: Faktorfaktor yang mempengaruhi konsumsi kayu energi rumah tangga pedesaan kasus
Sukabumi. Pusat Penelitian Sosial Ekonomi dan Kebijakan Kehutanan, Bogor.

Astana, S. 2009. Laporan Hasil Penelitian III: Faktor-faktor yang mempengaruhi konsumsi kayu energi rumah tangga pedesaan kasus Lebak. Pusat Penelitian Sosial Ekonomi dan Kebijakan Kehutanan, Bogor.

BPKH. 2009. Potensi kayu dan karbon hutan rakyat di Pulau Jawa Tahun 1990 - 2008. Hasil Kerjasama BPKH XI dengan MFP II.

Dillon, W. R. and M. Goldstein. 1984. Multivariate analysis: methods and applications. John Wiley and Sons, New York.

Kennedy, P. 1994. A Guide to econometrics. $3^{\text {rd }}$ Ed. MIT Press, Cambridge.

Tomek, William G. and Kenneth L. Robinson. 1985. Agricultural Product Prices. Second Ed. Cornell Univ. Press. London. 